\title{
SURVEI FAKTOR PENYEBAB PEROKOK REMAJA MEMPERTAHANKAN PERILAKU MEROKOK
}

Fitri Almaidah, Saarah Khairunnisa, Intan Purnama Sari, Chaza Deidora Chrisna, Anisa Firdaus, Zakiyatul Hurroh Kamiliya, Ni Putu Williantari, Achmad Naufal Maulana Akbar, Luh Putu Ariyani Pratiwi, Kiki Nurhasanah, Hanni Prihhastuti Puspitasari*

Fakultas Farmasi, Universitas Airlangga

Gedung Nanizar Zaman Joenoes Kampus C, J1. Ir. Soekarno, Surabaya 60115, Indonesia

Email: hanni-p-p@ff.unair.ac.id

\begin{abstract}
ABSTRAK
Jawa Timur menempati peringkat ke-16 se-Indonesia dengan tingkat perokok usia remaja yang cukup tinggi. Penelitian dilakukan untuk mengidentifikasi alasan remaja di Surabaya berusia 15-19 tahun mempertahankan perilaku merokok. Metode yang digunakan adalah observasional cross sectional dengan accidental sampling dan dianalisis menggunakan program SPSS. Instrumen yang digunakan berupa kuesioner berisi tentang pengalaman perilaku merokok, pengetahuan bahaya merokok, sikap mempertahankan merokok dan perilaku setelah mengetahui bahaya merokok. Sejumlah 103 remaja berpartisipasi dalam penelitian ini yaitu remaja yang masih merokok sampai saat ini $(80,6 \%)$ maupun yang pernah merokok $(19,4 \%)$. Sumber pengaruh terbesar remaja mencoba merokok berasal dari teman $(62,65 \%)$. Bahaya merokok yang paling banyak diketahui adalah kanker paru $(87,4 \%)$. Informasi ini paling banyak diketahui dari bungkus rokok $(60,2 \%)$. Sebagian besar responden telah mengetahui bahaya merokok, tetapi tetap mempertahankan sikap merokok $(62,2 \%)$. Hal ini dipengaruhi oleh aspek psikologi seperti dapat melepaskan stress $(69,9 \%)$ dan merasa tenang ketika merokok $(69,0 \%)$. Perilaku merokok dipertahankan untuk memenuhi kepuasan pribadi.
\end{abstract}

Kata kunci: merokok, mempertahankan, perokok, remaja, Surabaya

\begin{abstract}
Among 34 provinces, East Java has the $16^{\text {th }}$ highest rate of teenage smokers. The study aimed to identify factors influencing teenagers in Surabaya aged 15-19 years maintain their smoking habits. A cross sectional observational study was conducted with accidental sampling, analyzed using SPSS. A self administered questionnaire was used, containing experiences of smoking behavior, knowledge of the dangers of smoking, attitudes to maintaining smoking and behavior after knowing the dangers of smoking. About 103 teenages parcipitated, both either past $(19,4 \%)$ or current smoking experience $(80,6 \%)$. It was reported that friends $(62.65 \%)$ were the biggest influence of trying smoking. Most respondents agreed that smoking is causing lung cancer $(87.4 \%)$. Such information was mostly obtained from cigarette packs $(60.2 \%)$. Eventhough some respondents admitted the dangers of smoking, some showed attitude towards maintaining smoking (62.2\%). Psychological aspects such as beliefs that smoking releases worry $(69.9 \%)$ and feel calm when smoking $(69.0 \%)$. In conclusion, smoking is considered to fulfill their personal satisfaction.
\end{abstract}

Keywords: smoking, smoke behaviour, smokers, teenagers, Surabaya 


\section{PENDAHULUAN}

Rokok adalah salah satu produk tembakau, dimaksudkan untuk dibakar dan dihisap dan/atau dihirup asapnya termasuk rokok putih, rokok kretek, rokok cerutu atau bentuk lainnya. Rokok dapat dibuat dari Micotina tobacum, Nicotiana rustica, spesies lainnya atau sintetisnya yang asapnya mengandung nikotin dan tar, dengan atau tanpa bahan tambahan (Kemenkes RI, 2013). Berdasarkan data World Health Organization tahun 2019, tembakau membunuh lebih dari 8 juta orang per tahun di seluruh dunia. Lebih dari 8 juta kematian tersebut dihasilkan dari penggunaan tembakau secara langsung, sementara sekitar 1,2 juta kematian itu dialami oleh perokok pasif. Negara pada Association of South East Asian Nations (ASEAN) merupakan kawasan dengan $10 \%$ dari seluruh perokok di dunia dan kawasan dengan $20 \%$ penyebab kematian global akibat tembakau. Data tersebut juga menyebutkan bahwa Indonesia merupakan negara dengan persentase perokok terbanyak di negara ASEAN (lebih dari 50\%) (Drope \& Neil, 2018). Jumlah perokok aktif terbanyak pada usia remaja (10-18 tahun) mengalami peningkatan dari $7,2 \%$ di tahun 2013 menjadi 9,1 \% di tahun 2018. Provinsi Jawa timur menempati peringkat ke-16 se-Indonesia sebagai wilayah dengan tingkat perokok usia remaja yang cukup tinggi (Kemenkes RI, 2018).

Sebuah penelitian menunjukkan bahwa penyebab para remaja mulai merokok yakni dari peralihan masa kanak-kanak ke masa remaja banyak menimbulkan kesulitan dalam penyesuaian terhadap dirinya maupun terhadap lingkungan sosial. Berbagai kesulitan dalam penyesuaian diri membawa dampak pada sikap yang muncul sebagai cerminan pribadinya yang masih labil. Keinginan untuk diakui sebagai orang dewasa seringkali diikuti dengan meniru kebiasaan orang dewasa tanpa disertai oleh pemikiran yang matang. Padahal berbagai pilihan yang diambil pada masa remaja merupakan hal penting yang dapat berakibat langsung terhadap sikap dan perilaku serta berdampak panjang. Dunia pergaulan remaja yang memasukan merokok sebagai salah satu pembangun eksistensi diri memunculkan sikap acuh terhadap berbagai dampak negatif yang diakibatkan (Rochayati \& Hidayat, 2015).

Ketersediaan beragam informasi mengenai bahaya dan dampak negatif merokok sudah cukup banyak di masyarakat. Seperti yang dilansir oleh salah satu media berita online, Detik Health tahun 2019 menjelaskan mengenai dampak merokok yang dapat meningkatkan risiko serangan stroke berulang dan bahaya tar bagi paru sampai ke otak. Manifestasi berupa ilustrasi gambar yang tertera di kemasan rokok seperti kanker mulut, kanker paru, kanker tenggorokan, dan sebagainya. Data WHO (2011) menunjukkan bahwa sebanyak 82,5\% orang menyadari iklan mengenai rokok dan sebanyak $72,2 \%$ perokok mengetahui peringatan yang terdapat pada kemasan rokok tetapi hanya $27,1 \%$ perokok yang berpikir untuk berhenti merokok setelah melihat peringatan tersebut. Berdasarkan fenomena tersebut, maka dilakukan survei mengenai alasan perokok usia remaja di Indonesia tetap mempertahankan perilaku merokok. Penelitian ini dilakukan di beberapa wilayah di Surabaya yang terdiri dari wilayah Surabaya Pusat, Surabaya Selatan, dan Surabaya Timur.

\section{METODE PENELITIAN}

\section{Desain penelitian dan teknik sampling}

Penelitian ini dilakukan dengan studi cross sectional. Pengambilan data dilakukan dengan survei pada tanggal 13-19 September 2019 di lingkungan SMA/SMK di Surabaya. Instrument yang digunakan berupa kuesioner. Pengambilan sampel dilakukan secara accidental yaitu responden yang terpilih memenuhi kriteria inklusi. Accidental sampling adalah teknik penentuan sampel berdasarkan kebetulan, yaitu responden yang secara kebetulan bertemu dengan peneliti dapat digunakan sebagai sampel bila dipandang orang yang kebetulan ditemui tersebut cocok sebagai sumber data (Sugiyono, 2009). Responden yang ditemui diantaranya berada di kawasan Surabaya Pusat, Surabaya Selatan, dan Surabaya Timur.

\section{Kriteria inklusi}

Populasi penelitian adalah remaja perokok di Surbaya. Kriteria inklusi yang ditetapkan adalah remaja usia 15-19 tahun di Surabaya, sedang menjadi perokok aktif maupun pernah merokok dan sudah tidak merokok lagi, serta bersedia menjadi responden.

\section{Instrumen}

Kuesioner terdiri dari 4 bagian pertanyaan. Bagian A berisi tentang identitas responden berupa usia dan jenis kelamin. Bagian B berisi tentang perilaku merokok responden meliputi apakah responden merupakan perokok aktif atau sudah tidak merokok lagi (bagi responden yang sudah tidak merokok maka diberikan arahan langsung mengisi bagian C), lama merokok, umur mulai merokok, alasan pertama kali mulai merokok, orang yang mempengaruhi untuk 
merokok, jumlah batang rokok yang dihabiskan dalam sehari, serta keadaaan yang dapat membuat responden untuk merokok.

Bagian $\mathrm{C}$ berisi pertanyaan perspektif responden tentang bahaya merokok, bahaya merokok apa saja yang diketahui, dari sumber atau media apa responden memperoleh informasi bahaya merokok, serta tindakan apa yang dilakukan responden setelah mengetahui bahaya merokok. Bagian terakhir, yaitu bagian $\mathrm{D}$ berisi tentang pernyataan mengenai pemikiran yang mendukung sikap responden mempertahankan perilaku merokok.

Kuesioner bagian A, B, dan C, tersedia pilihan jawaban ya atau tidak, atau memilih jawaban yang tersedia. Sedangkan pada bagian D, diberi rentang skor 1-4 dengan opsi sangat tidak setuju (1), tidak setuju (2), setuju (3), dan sangat setuju (4).

\section{Analisis data}

Analisis data deskriptif dengan pendekatan kuantitatif, dengan menyajikan frekuensi dan persentase setiap jawaban dari pertanyaan dan tingkat persetujuan terhadap pernyataan dari sikap, dilakukan menggunakan software IBM Statistical Product and Services Solution (SPSS) 21.

\section{HASIL DAN PEMBAHASAN}

Sebanyak 103 responden remaja berpartisipasi dalam penelitian, 83 responden $(80,6 \%)$ masih merokok hingga sekarang, sedangkan sisanya yaitu 20 responden $(19,4 \%)$ sudah tidak merokok. Pengalaman perilaku merokok oleh 83 responden ditunjukkan pada Tabel 1.

Tabel 1. Pengalaman Perilaku Merokok pada 83 Responden Remaja

\begin{tabular}{lc}
\hline Topik pertanyaan & $\mathrm{n}(\%)$ \\
\hline Lama merokok: & \\
$\geq 1$ tahun & $53(63,86)$ \\
$<1$ tahun & $30(36,14)$ \\
\hline Umur mulai merokok: & \\
$>15$ tahun & $46(55,42)$ \\
$11-15$ tahun & $33(39,76)$ \\
$\leq 10$ tahun & $4(4,82)$ \\
\hline Alasan pertama kali merokok $(*):$ & \\
Iseng / ingin mencoba & $53(63,86)$ \\
Diajak teman & $18(21,69)$ \\
Stress & $13(15,66)$ \\
Mencontoh orangtua & $5(6,02)$ \\
Agar terlihat dewasa / keren & $4(4,82)$ \\
\hline Sumber pengaruh merokok pertama: & \\
Teman & $52(62,65)$ \\
Tidak ada & $23(27,71)$ \\
Anggota keluarga & $4(4,82)$ \\
Iklan & $2(2,41)$ \\
\hline
\end{tabular}

\begin{tabular}{lc}
\hline Jumlah rokok per hari : & \\
$1-5$ batang & $57(68,68)$ \\
$6-10$ batang & $15(18,07)$ \\
$>10$ batang & $11(13,25)$ \\
\hline Keadaan untuk merokok $\left(^{*}\right):$ & $33(39,76)$ \\
Ingin merokok & $30(36,14)$ \\
Merasa stres & $27(32,53)$ \\
Berkumpul dengan teman & $20(24,10)$ \\
Mulut tidak enak & $18(21,69)$ \\
Merasa bosan & $9(10,84)$ \\
Mengantuk & $5(6,02)$ \\
Melihat orang merokok & \\
\hline \hline
\end{tabular}

(*) jawaban dapat dipilih lebih dari satu opsi

Dari Tabel 1, didapatkan data 53 dari 83 responden $(63,86 \%)$ telah merokok lebih dari 1 tahun. Hal ini menunjukkan bahwa banyak remaja yang masih mempertahankan perilaku merokok. Remaja mulai merokok paling banyak adalah pada usia > 15 tahun $(55,42 \%)$. Data tersebut relevan dengan data InfoDatin (2015) yang menunjukkan bahwa usia merokok pertama kali paling tinggi adalah pada kelompok umur 15 - 19 tahun.

Berdasarkan hasil survei alasan remaja pertama kali merokok, responden paling banyak memilih alasan iseng atau ingin mencoba $(63,86 \%)$. Hal tersebut sesuai dengan pernyataan bahwa remaja memiliki rasa ingin tahu yang tinggi, maka cenderung untuk mencoba hal baru (Melda, 2017). Alasan remaja merokok karena ingin mencoba hal baru bisa dikaitkan dengan hasil survei mengenai pengaruh merokok pertama tertinggi adalah karena pengaruh teman $(62,65 \%)$. Keingintahuan remaja dengan mencoba merokok bukanlah karena dirinya, tetapi pergaulan dengan teman perokok menjadi salah satu faktor pendorong yang kuat. Lingkungan teman sebaya merupakan pihak yang pertama kali mengenalkan perilaku merokok, sedangkan teman sebaya mempunyai peran yang sangat berarti bagi remaja karena masa tersebut remaja mulai memisahkan diri dari orang tua dan mulai bergabung pada kelompok sebaya (Sutha, 2016).

Jumlah rokok yang dikonsumsi oleh remaja per hari tergolong rendah yaitu $1-5$ batang per hari $(68,68 \%)$. Hasil ini didukung oleh penelitian sebelumnya (Aldani dkk., 2016) yang menunjukkan bahwa diantara 94 remaja yang merokok sebanyak $47 \quad(50 \%)$ responden mengkonsumsi rokok sebanyak 1-5 batang setiap hari. Hal ini menunjukkan bahwa remaja merupakan perokok ringan, karena remaja baru memulai merokok.

Hasil survei menunjukkan sejumlah responden $(39,76 \%)$ mempunyai keinginan merokok untuk mendapatkan kenikmatan dan 
kesenangan merokok. Sejumlah responden $(36,14 \%)$ merasa stres menjadi pemicu bagi remaja untuk merokok. Konsumsi rokok ketika stres merupakan usaha mengatasi masalah yang bersifat emosional atau sebagai kompensasi kecemasan yang diahlikan terhadap perilaku merokok (Komasari \& Helmi, 2000).

Sebagian besar responden $(86,4 \%)$ mengetahui bahwa merokok berbahaya bagi kesehatan. Pemikiran ini sejalan dengan penelitian Wijayanti, dkk (2017) pada responden berusia 10-19 tahun yang diperoleh data $65 \%$ responden memiliki pengetahuan yang baik tentang bahaya merokok. Persentase pengetahuan responden mengenai bahaya merokok terkait dampak merokok, sumber informasi, serta subjek terdampak bahaya merokok sesuai Tabel 2.

Tabel 2. Pengetahuan Bahaya Merokok pada 83 Responden Remaja

\begin{tabular}{cll}
\hline \hline No. & Pengetahuan bahaya merokok & Presentasen $(\%)$ \\
\hline & Dampak merokok : $\left(^{*}\right)$ & \\
& Kanker paru-paru & $90(87,4)$ \\
& Penyakit jantung & $46(44,7)$ \\
1. & Kanker mulut & $45(43,7)$ \\
& Kematian & $45(43,7)$ \\
& Kecacatan janin & $36(35)$ \\
& Impotensi & $30(29,1)$ \\
\hline & Sumber informasi : $\left(^{*}\right)$ & $62(60,2)$ \\
& Bungkus rokok & $45(43,7)$ \\
2. & Median sosial & $43(41,7)$ \\
& Sosialisasi/penyuluhan & $35(34)$ \\
& Buku & $19(18,4)$ \\
\hline & Subjek terdampak : $(*)$ & \\
Orang di sekitar perokok & $92(57,3)$ \\
Keduanya & $33(32)$ \\
& Diri sendiri & $44(10,7)$ \\
\hline \hline
\end{tabular}

(*) jawaban dapat dipilih lebih dari satu opsi

Berdasarkan Tabel 2, sebagian responden mengetahui berbagai dampak negatif dari bahaya merokok. Namun, sumber pengetahuan terkait bahaya merokok paling banyak didapatkan melalui bungkus rokok $(60,2 \%)$, padahal informasi pada bungkus rokok sangat terbatas. Hal ini sesuai dengan Peraturan Pemerintah No. 109 Tahun 2012 pasal 17 ayat 2 tentang informasi pada bungkus rokok hanya mencantumkan satu jenis gambar dan tulisan peringatan kesehatan. Responden banyak mendapatkan informasi dari bungkus rokok dikarenakan bungkus rokok paling mudah diakses. Selain itu, berdasarkan penelitian didapatkan data bahwa sumber informasi tentang bahaya merokok melalui sosialisasi (34\%) ternyata masih kurang, sehingga perlu ada upaya baik dari pemerintah maupun masyarakat untuk meningkatkan pengetahuan remaja mengenai bahaya merokok melalui sosialisasi. Beberapa buku mencantumkan informasi tentang bahaya merokok yang cukup lengkap seperti pada buku berjudul "Pembunuh Berbahaya Itu Bernama Rokok", buku berjudul "Mengenal Rokok dan Bahayanya", serta buku tentang bahaya rokok lainnya. Namun, sumber informasi dari buku sulit diakses dan umumnya berbayar sehingga sumber informasi dari buku mendapatkan presentase yang paling rendah $(18,4 \%)$.

Sebenarnya informasi tentang bahaya merokok sudah sering disosialisasikan oleh pemerintah melalui Kementerian Kesehatan. Kementerian Kesehatan juga memiliki program gerakan masyarakat (Germas) yaitu hidup sehat tanpa rokok dengan modul yang mudah diakses di internet, dan informasi yang disertai gambar sehingga menarik untuk dibaca (Kemenkes, 2017). Namun memang program seperti ini perlu lebih digencarkan lagi guna menekan prevalensi perokok remaja di Indonesia. Hasil penelitian menunjukkan sejumlah responden $(57,3 \%)$ mempunyai pengetahuan bahwa subyek terdampak bahaya merokok itu untuk orang disekitar perokok saja. Hal ini menunjukkan bahwa masih banyak perokok remaja lebih mementingkan diri sendiri tanpa memperhatikan orang lain.

Sikap remaja mempertahankan merokok dikelompokkan menjadi tiga kategori yaitu kategori terkait psikologis responden, hubungan dengan orang lain (sosial), dan pernyataan yang mengarah kepada jati diri. Pengelompokan ini sesuai pernyataan bahwa masa remaja merupakan tahap transisional yang mempengaruhi psikologis dan kehidupan sosial seorang remaja (Purwadi, 2004). Masa remaja 
cenderung menegaskan eksistensi dan jati diri (Marcia, 1993). Pernyataan-pernyataan tersebut didasarkan pada data yang ada pada Tabel 3 berikut.

Tabel 3. Persentase Sikap Merokok pada 103 Responden Remaja

\begin{tabular}{clcc}
\hline \hline \multirow{2}{*}{ No. } & \multicolumn{1}{c}{ Pernyataan } & $\begin{array}{c}\text { Setuju } \\
\mathrm{n}(\%)\end{array}$ & $\begin{array}{c}\text { Tidak setuju } \\
\mathrm{n}(\%)\end{array}$ \\
\hline 1. & Merokok atau tidak semua orang akan mengalami kematian $(\mathrm{P})$ & $80(77,6)$ & $23(22,4)$ \\
\hline 2. & Merokok dapat melepaskan stres saya (P) & $72(69,9)$ & $31(30,1)$ \\
\hline 3. & Merokok dapat membuat saya merasa tenang (P) & $71(69,0)$ & $32(31,0)$ \\
\hline 4. & $\begin{array}{l}\text { Saya akan tetap merokok meskipun sudah mengetahui bahaya } \\
\text { merokok (P) }\end{array}$ & $64(62,1)$ & $39(37,9)$ \\
\hline 5. & Saya memiliki cukup uang untuk membeli rokok (S) & $59(57,3)$ & $44(42,7)$ \\
\hline 6. & Dengan merokok konsentrasi saya lebih meningkat (P) & $49(47,6)$ & $54(52,4)$ \\
\hline 7. & Saya tetap sehat meskipun merokok (P) & $49(47,6)$ & $54(52,4)$ \\
\hline 8. & Saya merasa ketagihan merokok (P) & $68(46,6)$ & $55(53,4)$ \\
\hline 9. & Mulut saya terasa hambar jika tidak merokok (P) & $46(44,7)$ & $57(55,3)$ \\
\hline 10. & Merokok dapat meningkatkan hubungan sosial saya (S) & $45(43,7)$ & $58(56,3)$ \\
\hline 11. & Merokok merupakan kebutuhan hidup saya (P) & $29(28,2)$ & $74(71,8)$ \\
\hline 12. & Tidak ada yang melarang saya untuk merokok (S) & $29(28,2)$ & $74(71,8)$ \\
\hline 13. & Saya merasa lebih percaya diri jika merokok (JD) & $26(25,2)$ & $77(74,8)$ \\
\hline 14. & Merokok adalah sesuatu yang keren bagi saya (JD) & $15(14,6)$ & $88(85,4)$ \\
\hline 15. & Saya dipandang dewasa jika saya merokok (JD) & $10(9,7)$ & $93(90,3)$ \\
\hline \hline
\end{tabular}

Keterangan :

$\mathrm{P}=$ Psikologis

$\mathrm{S}=$ Sosial

$\mathrm{JD}=$ Jati Diri

Karakteristik remaja saat ini adalah manja dan cenderung egois (Toro, 2012). Sikap ini sesuai dengan analisis data hasil kuesioner yang menunjukkan bahwa banyak responden menyatakan tidak setuju terhadap pernyataan pada Tabel 3 yang ditujukan untuk diri sendiri dalam aspek psikologis yaitu pernyataan nomor 1-4, 6-9, dan 11. Persentase empat teratas dari jawaban pernyataan pada Tabel 3 menunjukkan bahwa responden siswa dengan pendidikan sekolah menegah atas (SMA) cenderung lebih mementingkan ego daripada keadaan orang lain. Siswa SMA yang merokok menyatakan merasa senang dan dapat melepaskan stres yang merupakan pernyataan terkait psikologis. Persentase paling tinggi ketika responden ditanya terkait sikap terhadap kematian akibat merokok. Terlihat jelas bahwa responden secara alam bawah sadar menyatakan bahwa merokok tidak berbahaya karena semua orang akan mengalami kematian. Pemikiran ini sangat fatal, karena merokok memiliki kontribusi besar terhadap berbagai komplikasi penyakit penyebab kematian pada perokok aktif ataupun perokok pasif (Centers for Disease Control and Prevention, 2019). Selain itu, pada pernyataan nomor 4 dan 7 dalam Tabel 3 menunjukkan bahwa sebenarnya responden tahu bahwa merokok adalah perilaku yang tidak sehat, namun tradisi merokok dengan berkumpul bersama teman masih tetap dilakukan. Sikap ini menunjukkan bahwa remaja mempertahankan perilaku merokok untuk mengejar kenikmatan secara pribadi, tanpa mempedulikan kesehatan.

Pernyataan nomor 5, 10, dan 12 pada Tabel 3 merupakan kelompok pernyataan sosial dengan pernyataan nomor 5 tentang hubungan antara responden dan orang tua memiliki persentase persetujuan terhadap pernyataan paling tinggi (59\%). Secara tidak langsung orang tua memiliki pengaruh terhadap sikap merokok pada remaja. Hal tersebut dapat dipicu oleh uang yang diterima remaja pada umumnya merupakan uang saku dari orang tua. Pemberian uang saku yang jumlahnya tidak terkontrol dapat disalahgunakan untuk melakukan perilaku salah seperti merokok. Hal ini didukung oleh hasil penelitian yang menyatakan bahwa terdapat korelasi positif antara jumlah uang saku dan konsumsi rokok pada remaja (Scragg et al, 2002). Sebaliknya, pada pernyataan nomor 12 , sejumlah 73 responden $(70,8 \%)$ menyatakan tidak setuju. Sebenarnya ada larangan merokok untuk remaja, tetapi remaja tetap mempertahankan sikap merokok. Hal ini didukung oleh teori yang menyatakan bahwa remaja cenderung mengambil risiko dan menjunjung tinggi kebebasan (Badan Pusat Statistika, 2018).

Pernyataan nomor 13, 14, dan 15 pada Tabel 3 merupakan kelompok pernyataan jati diri dengan pernyataan nomor 13 memiliki persentase persetujuan pernyataan paling tinggi $(25,2 \%)$. Hal ini didukung oleh teori yang 
menyatakan bahwa perilaku merokok merupakan salah satu cara negatif untuk membangun rasa percaya diri pada remaja (Haryono, 2007). Walaupun demikian, lebih dari $70 \%$ responden memilih tidak setuju untuk tiap pernyataan dalam kelompok ini. Hal ini menunjukkan bahwa sikap mempertahankan merokok yang dilakukan oleh remaja adalah bukan bentuk pencarian jati diri. Hasil ini tidak sesuai dengan teori yang menyatakan bahwa merokok merupakan salah satu bentuk kenakalan remaja dalam mencari jati diri (Santrock, 2003) dan perilaku simbolis yang menunjukkan kematangan (Brigham, 1991).

Pengetahuan dan sikap pada individu akan membentuk sebuah tindakan/praktik berupa perilaku (Notoatmodjo, 2012). Setelah responden remaja mempunyai pengetahuan tentang bahaya merokok dan sikap merokok pada diri individu remaja maka akan menimbulkan sebuah perilaku. Perilaku yang akan terjadi antara lain mengurangi konsumsi rokok pada $(34,3 \%)$ responden, berusaha berhenti merokok $(32,4 \%)$, perilaku tetap merokok $(23,5 \%)$, perilaku membagikan informasi $(21,6 \%)$, menghindari merokok di tempat umum $(15,7 \%)$, dan perilaku tidak peduli ditunjukkan oleh $(11,8 \%)$ responden dengan setiap responden dapat memilih lebih dari satu opsi jawaban (Tabel 4). Hasil penelitian ini menunjukkan bahwa tindakan untuk mengurangi konsumsi merokok berada pada tingkat pertama yang berarti sebenarnya responden memiliki keinginan untuk berhenti merokok tetapi banyak faktor penyebab untuk mempertahankan perilaku merokok tersebut.

Tabel 4. Perilaku Setelah Responden Mengetahui Bahaya Merokok

\begin{tabular}{lll}
\hline \hline No. & Tindakan/praktik (Perilaku) & Persentase \\
\hline 1. & Tidak peduli & $12(11,7)$ \\
\hline 2. & Tetap merokok & $24(23,3)$ \\
\hline 3. & $\begin{array}{l}\text { Menghindari merokok di } \\
\text { tempat umum }\end{array}$ & $16(15,5)$ \\
\hline 4. & Mengurangi konsumsi rokok & $35(34)$ \\
\hline 5. & Berusaha berhenti merokok & $33(32)$ \\
\hline 6. & Membagi info bahaya rokok & $22(21,4)$ \\
\hline \hline
\end{tabular}

(*) jawaban dapat dipilih lebih dari satu opsi

\section{KESIMPULAN}

Berdasarkan survei yang telah dilakukan, perilaku merokok pada remaja sebagian besar dimulai pada usia 15 tahun. Sumber pengaruh terbesar untuk merokok berasal dari pengaruh dari teman dengan alasan iseng atau hanya mencoba. Sebagian besar responden mengetahui bahwa perilaku merokok membahayakan kesehatan seperti terjadi kanker paru dan penyakit jantung. Pengetahuan tersebut sebagian besar diperoleh dari bungkus rokok. Alasan remaja untuk mempertahankan sikap merokok adalah adanya perasaan tenang dan melepaskan stres ketika merokok. Rendahnya kesadaran perokok untuk menghentikan perilaku merokok merupakah indikator perlu dilakukan usaha untuk menurunkan prevalensi perokok remaja dengan mengadakan kegiatan promosi kesehatan.

\section{DAFTAR PUSTAKA}

Aldani, NA, Usman, S, Tahlil, T 2016, 'Pengaruh peringatan visual pada bungkus rokok terhadap perilaku merokok pada siswa SMA', Jurnal Ilmu Keperawatan, 392), 1-9.

Anwar, F 2019, Merokok Disebut Peneliti Bisa Tingkatkan Risiko Serangan Stroke Berulang (viewed 6 September 2019), https://health.detik.com/beritadetikhealth/d4556274/merokok-disebut-peneliti-bisatingkatkan-risiko-serangan-stroke-berulang.

Badan Pusat Statistik Indonesia 2018, Profil Generasi Milenial Indonesia. Kementrian Pemberdayaan Perempuan dan Perlindungan Anak, Jakarta.

Brigham, JC 1991, Social Psychology, Haper Collins Publisher, New York.

Centers for Disease Control and Prevention 2019, Health Effect of Cigarette Smoking (viewed 6 September 2019), https://www.cdc.gov/tobacco/data_statistic s/fact_sheets/health_effects/effects_cig_s moking.

Drope, J, Neil, W 2018, The Tobacco Atlas, $6^{\text {th }}$ edition, The American Corner Society, Atlanta.

Haryono 2007, 'Hubungan Antara Ketergantungan Merokok Dengan Percaya Diri Pada Siswa SMAN 2 Blitar' Skripsi, Universitas Negeri Malang.

InfoDatin 2015, Hari Tanpa Tembakau Sedunia, Pusat Data dan Informasi Kementerian Kesehatan RI, Jakarta.

Jaya, M 2009, Pembunuh Berbahaya Itu Bernama Rokok, Riz'ma, Yogyakarta.

Kemenkes RI 2013, Keputusan Menteri Kesehatan Republik Indonesia Nomor 28 tentang Pencantuman Peringatan Kesehatan dan Informasi Kesehatan Pada Kemasan Produk Tembakau. Kemenkes RI, Jakarta.

Kemenkes RI 2017, GERMAS (Gerakan Masyarakat Hidup Sehat), Warta Kesmas, Jakarta. 
Kemenkes RI 2018, Riset Kesehatan Dasar (Riskesdas), Kemenkes RI, Jakarta.

Komasari, D, Helmi, AF 2000, 'Faktor-Faktor Penyebab Perilaku Merokok pada Remaja', Jurnal Psikologi, 1, pp. 37-47.

Marcia, JE, Waterman AS, Matteson, DR, Archer, SL, Orlofsky, JL 1993, Ego Identity: A Handbook for Psichological Research, Springer-Verlag, New York.

Melda, S 2017, 'Faktor-faktor penyebab remaja merokok (studi kasus remaja laki-laki di Kelurahan Karang Asam Ulu Kecamatan Sungai Kunjang, Kota Samarinda)', Journal Sosiatri-Sosiologi Fakultas Ilmu Sosial dan Ilmu Politik Universitas Mulawarman, 5(4), pp. 102-116.

Notoatmodjo, S 2012, Promosi Kesehatan dan Perilaku Kesehatan, Edisi Revisi, PT Rineka Cipt, Jakarta.

Pemerintah Republik Indonesia 2012, Peraturan Pemerintah Republik Indonesia Nomor 109 Tahun 2012 tentang Pengamanan Bahan yang Mengandung Zat Adiktif Berupa Produk Tembakau Bagi Kesehatan (viewed 15 Oktober 2019), https://sipuu.setkab.go.id/PUUdoc/173643/ PP1092012.pdf.

Purwadi 2004, 'Proses pembentukan identitas remaja', Humanities: Indonesia Psychologycal Journal, 1(1), pp. 43-52.

Rochayati, AS, Hidayat, E 2015, 'Faktor-faktor yang mempengaruhi perilaku merokok remaja di sekolah menengah kejuruan
Kabupaten Kuningan', Jurnal Keperawatan Soedirman, 1(10), pp. 1-11.

Santrock, JW 2003, Adolescence: Perkembangan Remaja, $6^{\text {th }}$ Ed, McGraw Hill College, New York.

Scragg, R 2002, 'Cigarette smoking, pocket money and socioeconomic status : results from a national survey of 4th from students in 2000' The New Zealand Medical Journal, 115(1158), pp. 1-8.

Sugiyono 2009, Metode Penelitian Kuantitatif, Kualitatif dan $R \& D$, Alfabeta, Bandung.

Sutha, DW 2016, 'Analisis lingkungan sosial terhadap perilaku merokok di kecamatan pangarengan Kabupaten Sampang Madura', Jurnal Manajemen Kesehatan STIKES Yayasan RS. Dr. Soetomo, 2(1), 43-59.

Toro, PW 2012, 'Empati yang menyembuhkan' Majalah Psikologi Plus, 7(4), pp. 183-188.

WHO 2011, Global Adult Tobacco Survey (GATS) Indonesia Report 2011 (viewed 3 September 2019), https://www.who.int/tobacco/surveillance/ survey/gats/indonesia/en/.

WHO 2019, 'Tobacco' (viewed 6 September 2019), https://www.who.int/newsroom/fact-sheets/detail/tobacco.

Wijayanti, E, Dewi, C, Rifqatussa'adah 2017, 'Faktor-faktor yang berhubungan dengan perilaku merokok pada Remaja Kampung Bojong Rawalele, Jatimakmur, Bekasi', Global Medical and Health Communication, 5(3), pp. 194-198. 